\title{
靯性改善を目的とした新形式鉄筋コンクリート柱の開発研究 DEVELOPMENT OF DUCTILE R/C COLUMN WITH A NEW CONCEPT
}

\author{
鈴木 敏 郎*, 滝口克已*, 宮下真一** \\ Toshiro SUZUKI, Katsuki TAKIGUCHI and Shin-ichi MIYASHITA
}

\begin{abstract}
In the reinforced concrete buildings, it is important to prevent the columns from shear failure and improve the seismic performance of the columns. It is well known that the shear reinforcement is effective to improve the behavior of the reinforced concrete column by confining the core concrete of the columns.

In this paper the authors present a new concept to improve the performance of columns subjected to large displacements in the inelastic range. To lead transverse cracks prevent slant cracks.caused the shear failure. In order to verify the adequacy of this concept two tests are conducted, one is the cyclic shear bending test and the other is the monotonic compression test. The following findings can be obtained.
\end{abstract}

1) The cyclic loading performance of this new R/C columns can be improved much by inserting steel plates.

2) By inserting steel plates the monotonic loading performance can be also improved.

3) These effectiveness are brought by separating concrete section and steel plates reinforcement.

4) Various method is existent to improve the seismic performance of R/C column.

Keywords : Column, Shear failure, Cyclic loading, Monotonic compression, Stable limit 柱, せん断破壊, 繰り返し曲げせん断実験, 一軸圧縮実験, 安定限界

\section{1，序論}

近年、鉄筋コンクリート構造物の設計においては、部 材の終局時の特性に立脚した設計法いわゆる終局強度型 の設計手法が提案されているい。この設計手法における 耐震性確保の考え方は、構造物に一定の水平耐力を保有 させ、かつ、そのときの変形をある限度内にとどめると いうものである。このとき構造物を構成する各部材は、 降伏を計画する部材と降伏を許容しない部材に分類さ れ、前者には十分な勒性能を持たせ、後者には十分な強 度を確保するものとしている。現在、この観点から鉄筋 コンクリート柱の勒性評価式および強度評価式が提案さ れているが、それらはある具体的な配筋方法に対して行 われいるのが現状である。ここで言う具体的な配筋方法 とは通常の配笳方法あるいはX形配筫等をさしている。 部材の勒性を向上させるための配筋方法は、数多く提案 されているが、現在最も一般的な方法は、横補強筋量を 多くし、主筋およびコンクリートを十分拘束するコン
ファインドコンクリートとすることである。横補強竻が コアコンクリートを拘束することにより、最大耐力以降 の負担圧縮応力の低下を防ぎ、その結果として限界曲率 を改善できることも確認されている22,3)。

筆者らも、鉄管コンクリート柱の勒性向上の方法を模 索しており、脆性破壊のうち特にせん断破壞の防止に着 目した方法として、コンクリート部分を水平に分断する という新しい形式を提案している4)。本論文では、新形 式の鉄筋コンクリート柱に関し、その概念と勒性向上に 対する有効性について考察する。

\section{2. 新形式の鉄筋コンクリート柱}

柱に要求される最も重要な性能は、軸力を安定的に保 持することである。逆に、せん断破壊は、変形の比較的 小さなところで、水平復元力ならびに軸力保持能力が急 激に低下する最も避けるべき破壊モードであるとされて いる。本論文で提案する新形式の鉄筋コンクリート柱
* 東京工業大学工学部建築学科 教授 $\cdot$ 工博

** 東京工業大学工学部建築学科 大学院生 (社会人プ ログラム), 東急建設 (株) 構造設計部・工修
Prof., Dept. of Architecture and Building Eng., Faculty of Eng., Tokyo Institute of Technology, Dr. Eng.

Graduate Student, Tokyo Institute of Technology, Struct. Eng., Structural Eng. Dept., Tokyu Construction Co., Ltd., M. Eng. 
は、コンクリート部分を水平に分断することによりこの せん断破壊を防止しようとしたものである。分断するこ とに期待した効果は、(1)あらかじめ水平ひび割れ（曲げ ひび割れ）を入れておくあるいは誘発することにより、 その部分に変形を集中させ、(2)ある程度の摩擦力を伝達 することを条件に、水平ひび割れ部での水平すべり変形 も許容し、(3)結果的に、部材全長につながる斜めひび割 れを防止あるいは遅延することである。これらの効果に より、最終的には部材に安定した復元力特性を保有させ ることが可能になると考えている。部材の危険断面位圆 に当初から水平ひび割れを設けることは、部材の水平復 元力に対して悪影響を及ぼすことはないものと考えられ るが、曲げモーメントが小さい部分での水平ひび割れお よびそれを誘発するために設けた装置の挙動あるいは大 変形時における水平ひび割れ部周辺の挙動は実験により 確認する必要がある。

\section{3. 圧縮曲げせん断実験}

\section{1 実験概要}

2 章で示した概念を導入した新形式の鉄筋コンクリー 卜柱の一定軸力下における繰り返し逆対称曲げせん断加 力実験を行った。試験体は、あらかじめ水平ひび割れを 入れておくことを目的に分断材として鎆板を用いたも の、水平ひび割れを早期に誘発することを目的として鋼 板フープを用いたものおよび従来の手法による標準試験 体の 3 種類である。コンクリートの分断材として用いた 鋼板は、(1)水平ひび割れを誘発すること、(2)部材全長に つながる斜めひび割れを防止あるいは遅延すること、(3) 斜めひび割れが発生したとしても、そのひび割れに沿っ たすべり変形を抑止することならびに(4)コンクリートと 鋼板の間に働く摩擦力を介して鋼板に働く引張力によっ てコンクリートを拘束することなどの効果をもたらすも のと考えられる。本形式の発想は、2 章でも述べたよう に(1)よび(2)の効果に着目したものであり、(3)よび(4) は、分断材に鋼板を用いたことにより付加された効果で ある。本論文では、(1)および(2)を「分断効果」、(3)お び(4)を「補强効果」、(1)〜(4)を総じて「鋼板挿入効果」 と呼ぶこととする。分断効果のみを抽出するという観点 からみれば、鋼板は結果的に補強効果も含むので分断材 として適切な材料ではないことになる。しかしながら、 コンクリートの打設時に分断材が変形することなく所定 の位置に設置されていることおよび試験体の軸方向剛性 が極端に小さくならないことを満足するものの中で理想 的ではないが現実的な選択として鋼板を使用した。

\section{(1) 試験体}

試験体は表一 1 に示す計 6 体である。各試験体の共通 事項は、断面が250x250mm、材長が500mm（シアスパン比 1.0）、主笳が6-D13（引張鉄能比0.61\%）である。
N40-S00-A30およびN46-S00-A60は、通常形式の試験体 であり、比較対照のためのものである。横補強筋には 6 $\phi$ 丸鋼を使用しており、横補強等形状は通常用いられて いる矩形とし、末端部は135度フックとしている。横補 強筋比は-A30で0.75\%、-A60で0.38\%である! 図ー1（a） にN40-S00-A30の試験体図およびその配笳を示す。

図－1（b）は、試験体材軸に対し垂直に鐝板を入れ、 コンクリートを層状に分断することによりあらかじめ水 平ひび割れを入れておくことを意図した試験体N40-S30A30の断面図である。N46-S60-A60についても鋼板間隔、 横補強筋間隔以外は同様である。鋼板は、厚さ0. $8 \mathrm{~mm}$ の ものを使用し、-S30は30 mm間隔、-S60は60mm間隔で試験 体の危険断面位置から $18 \mathrm{~cm}$ 範囲まで試験体内に配置し た。横補強筋比は通常形式のものと同一であり、-A30で

$$
\text { 表一 } 1 \text { 試験体一覧 }
$$

\begin{tabular}{|c|c|c|c|c|}
\hline Name of Specimen & Axial F. (kN) & Shear Reinf. & $\operatorname{Pr}(x)$ & Plate \\
\hline $\mathrm{N} 40-\mathrm{S} 00-130$ & $\therefore 390$ & $6 \phi-[]: 030$ & 0.75 & \\
\hline $\mathrm{N} 40-\mathrm{S} 30-\mathrm{A} 30$ & 390 . & 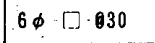 & 0.75 & Steel Plate 830 \\
\hline $\mathrm{N} 46-\mathrm{S} 00-\mathrm{A} 60$ & $\because 450$ & $6 \phi-[-860$ & 0.38 & \\
\hline $\mathrm{N} 46-\$ 60-\wedge 60$ & 450 & $6 \phi-[]-060$ & 0.38 & Steel Plate 960 \\
\hline N50-S0O-PH30 & 490 & $\mathrm{PH}-\square-030$ & 0.75 & Steel Plate 830 \\
\hline N50-S00-PH60 & 490. & PH $\cdot[]-060$ & 0.38 & Stee I Plate 060 \\
\hline
\end{tabular}
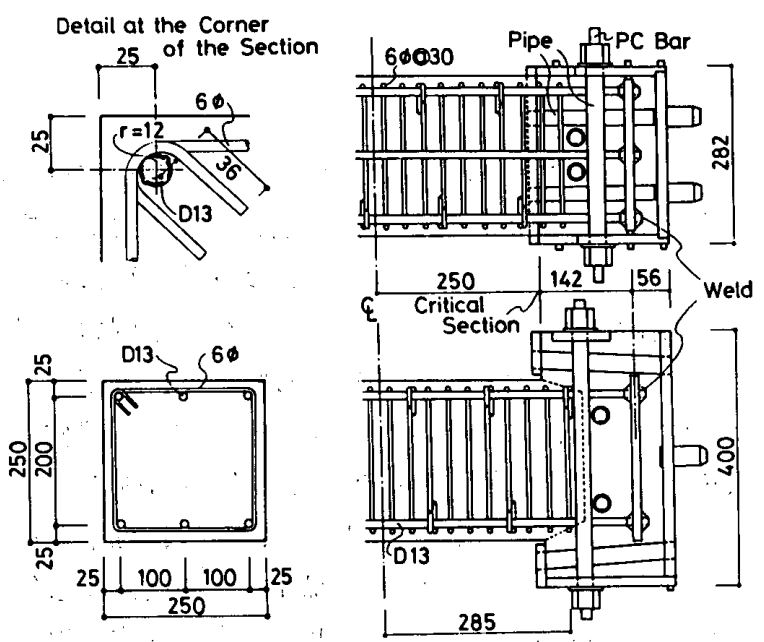

(a ) $\mathrm{N} 40-\mathrm{S} 00-\mathrm{A} 30$

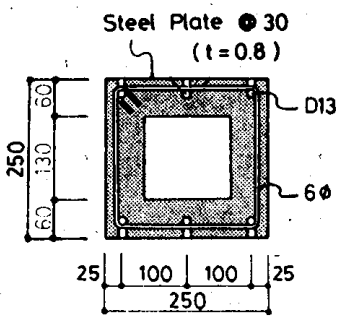

(b ) $\mathrm{N} 40-\mathrm{S} 30-\mathrm{A} 30$

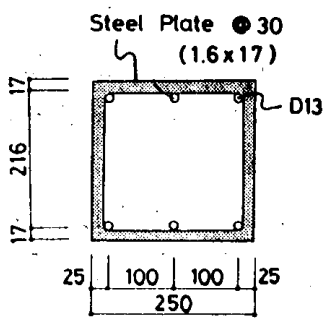

(c) $\mathrm{N} 50-\mathrm{S} 00-\mathrm{PH} 30$
図一 1 試験体図 
0.75\%、-A60で0. 38\%である。

図一 1 (c) は、N50-S00-PH30の断面図である。N50S00-PH60についても鋼板フープの間隔以外は同様であ る。これらの試験体は、N40-S30-A30およびN46-S60-A60 のように断面を大きく分断するのではなく、横補強䈘を 兼ねた鋼板フープで、かぶりコンクリートのみを分断す ることにより水平ひび割れを誘発することを意図したも のである。鋼板フープの断面積は $6 \phi$ 丸鋼と同一となる ようにしている。したがって、横補強笳比に換算すれ ば-PH30で0.75\%、-PH60で0.38\%となっている。

表 -2 鉄筋および鋼板の力学特性

\begin{tabular}{|c|c|c|c|c|c|}
\hline & $\underset{D / 3}{\text { Main Reinf. }}$ & Shear $\underset{6 \phi}{\operatorname{Re} \text { inf. }}$ & $\begin{array}{l}\text { Plate } \\
\text { PL 0.8 }\end{array}$ & $\begin{array}{l}\text { Plate Hoop } \\
\text { P'L } 1.6\end{array}$ \\
\hline \multicolumn{2}{|c|}{ Standardized Classification } & SD295A & SR235 & SS400 & SS 400 \\
\hline Yicld Strength & $(\mathrm{MPa})$ & 337 & 460 & 277 & 272 \\
\hline Tensile Strength & $(\mathbf{M P a})$ & 483 & 486 & 370 & 393 \\
\hline Elongation & (\$) & 25.0 & 14.9 & 25.0 & 31.0 \\
\hline
\end{tabular}

$$
\text { 表ー３ コンクリートの力学特性 }
$$

\begin{tabular}{|c|c|c|c|}
\hline Name of Specimen & $\left.\begin{array}{ccc}N 40 & S 00 & A 30 \\
(\quad S 30 & A 30\end{array}\right)$ & $\left(\begin{array}{ccc}N 46 & \$ 00 & A 60 \\
\quad & \$ 60 & A 60\end{array}\right)$ & 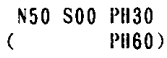 \\
\hline Age (days) & $15(22)$ & $28\langle 36\rangle$ & $44(48)$ \\
\hline $\begin{array}{c}\text { Compressive Strength } \\
\text { (MPa) }\end{array}$ & $50.2(52.1)$ & $58.8(61.1)$ & $63.4(60.5)$ \\
\hline $\begin{array}{l}\text { Strain at the Max. } \\
\text { Stress(y) }\end{array}$ & $0.18 \cdot 0.24$ & $0.20-0.25$ & $0.25 \quad 0.27$ \\
\hline $\begin{array}{l}\sigma^{\text {" } 3 \text { Sccant Modulus }} \\
\left(\times 10^{\circ} \mathrm{Pa}\right)\end{array}$ & 4. 0 & 3.0 & 4. 0 \\
\hline
\end{tabular}

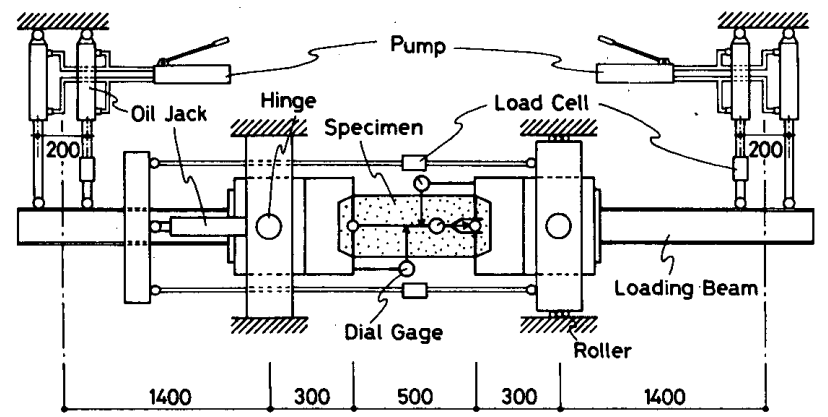

図 -2 ，実験装置

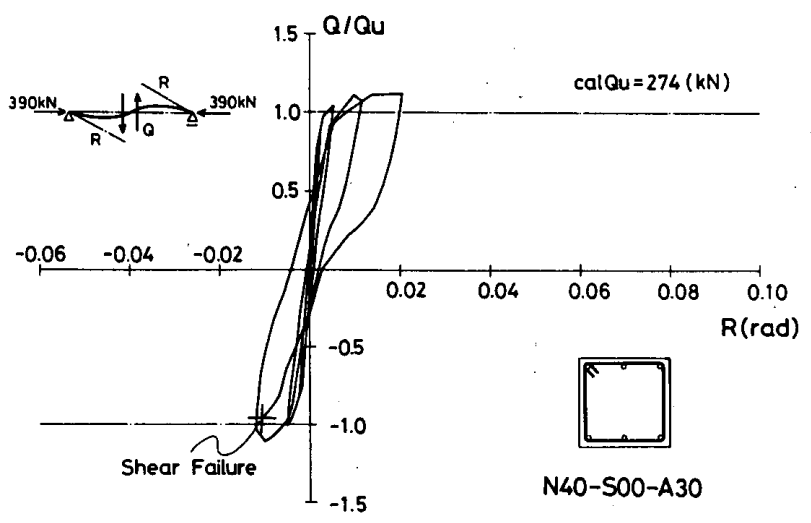

(a ) $\mathrm{N} 40-\mathrm{S} 00-\mathrm{A} 30$
（2）使用材料

表ー 2 に使用した鉄筋および鋼板の力学特性を示す。 主䈘にはSD295Aを使用し、横補強筋にはSR235を使用し ている。また、鋼板にはSS400を使用している。

表ー 3 に使用したコンクリートの力学特性を試験体別 に分けて示す。コンクリートの水セメント比は $33.3 \%$ と 全試験体共通である。

（3）加力および測定方法

図ー 2 に加力および測定装置を示す。試験体に逆対称 曲げせん断力を加えるために両側に各々 2 本ずつの油圧 ジャッキを取り付けている。

加力は一定軸力を保ちながら、試験体両端に逆対称強 制回転角を与えることにより行う。一定軸力は $\mathrm{N}=0.125 \mathrm{bD} \sigma \mathrm{B}$ とした。一荷重階で増加させる部材角の最 大值を、軸力変動が、士2\%以内になるように制御し、 変動した軸力は、各荷重階ごとに調整した。

変形履歷は、5.5サイクルの部材角漸増繰り返しと し、1/400,1/200,1/100,1/50,1/25 radの正負で 1 回 ずつ繰り返すものとし、目標最大部材角を $1 / 12.5 \mathrm{rad}$ した。

\section{2 実験結果}

図ー3〜図－5に各試験体の荷重一変形関係を示す。 縦軸は部材雨端部が曲げ耐力に達するときのせん断力で 無次元化したものであり、横軸は部材角である。曲げ耐 カは、コンクリート強度にシリンダー試験より得られた $\sigma \mathrm{B}$ 、鉄筋の降伏強度に引張試験より得られた $\sigma \mathrm{y}$ を用 い、各々の $\sigma-\varepsilon$ 関係を完全剛塑性と仮定して求めた。

図－3（a）は、通常形式で横補強筋が $30 \mathrm{~mm}$ 間隔で入っ ているN40-S00-A30の荷重一変形関係である。第 3 サイ クル（1/100rad）の正方向で斜めひび割れの発生が確認 されるとともにわずかな耐力低下が見られた。第 4 サイ クル $(1 / 50 \mathrm{rad})$ の正方向で耐力上昇がなくなり、同サ イクル負方向でせん断破壊し、軸力を保持できなくなっ た。

一方、図－3(b) は、N40-S00-A30 と同一条件で、鐝 板が $30 \mathrm{~mm}$ 間隔で入っているN40-S30-A30の荷重一変形関

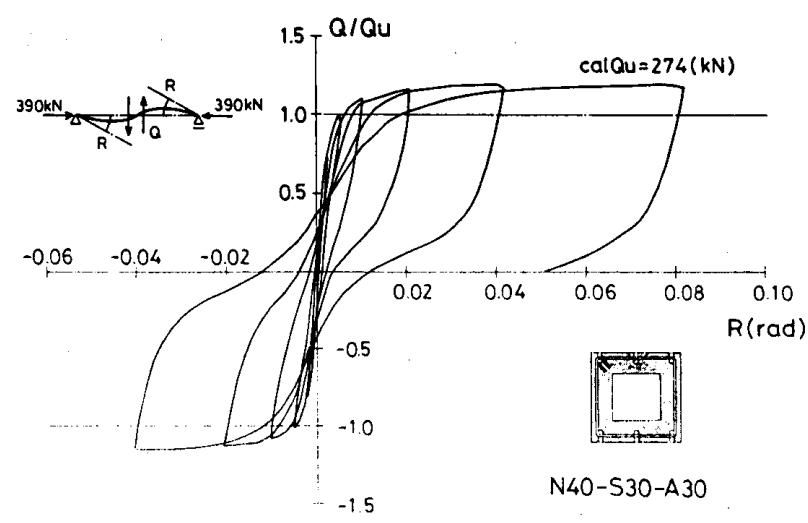

(b) $\mathrm{N} 40-\mathrm{S} 30-\mathrm{A} 30$

図 -3 荷重一変形関係 


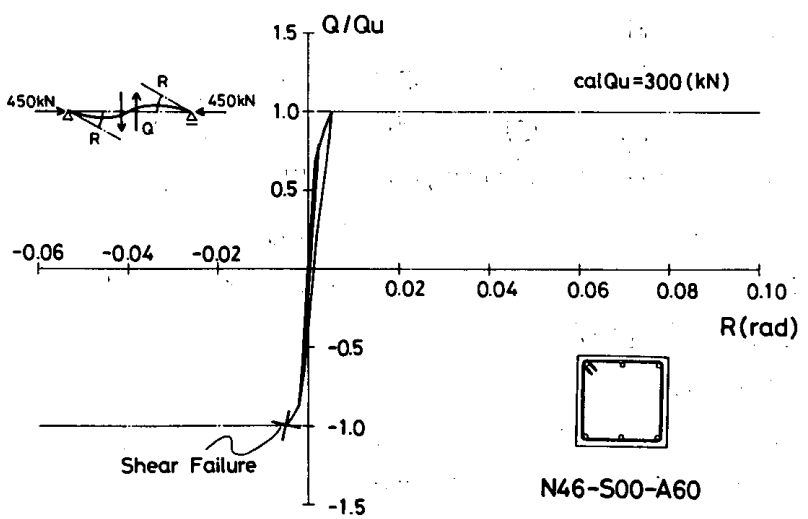

(a ) $\mathrm{N} 46-\mathrm{S} 00-\mathrm{A} 60$

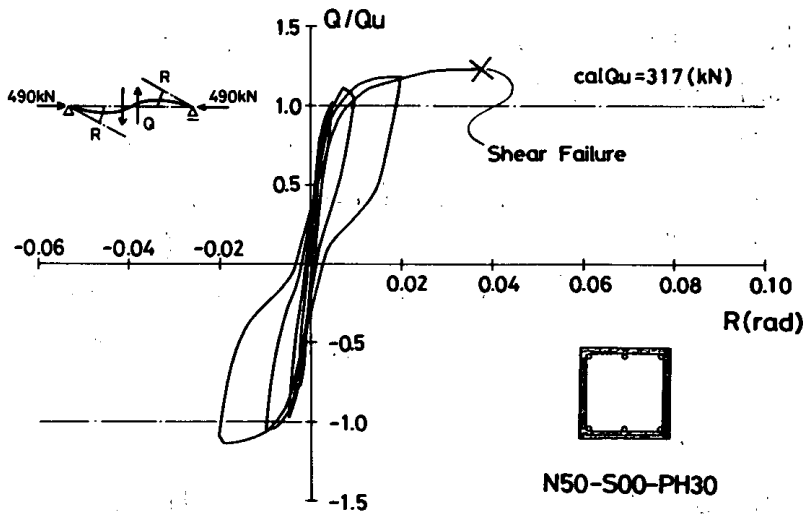

(a ) $\mathrm{N} 50-\mathrm{S} 00-\mathrm{PH} 30$

図 -5 荷重一変形関係

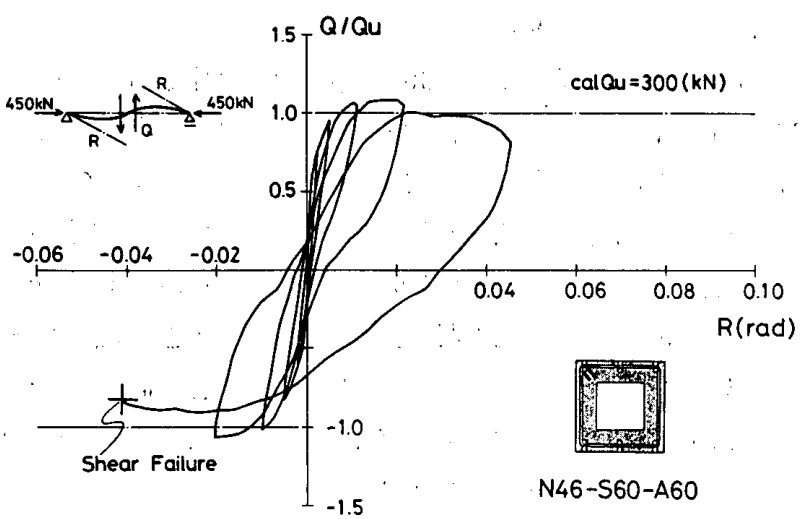

(b ) $\mathrm{N} 46-\mathrm{S} 60-\mathrm{A} 60$

図 -4 荷重一変形関係

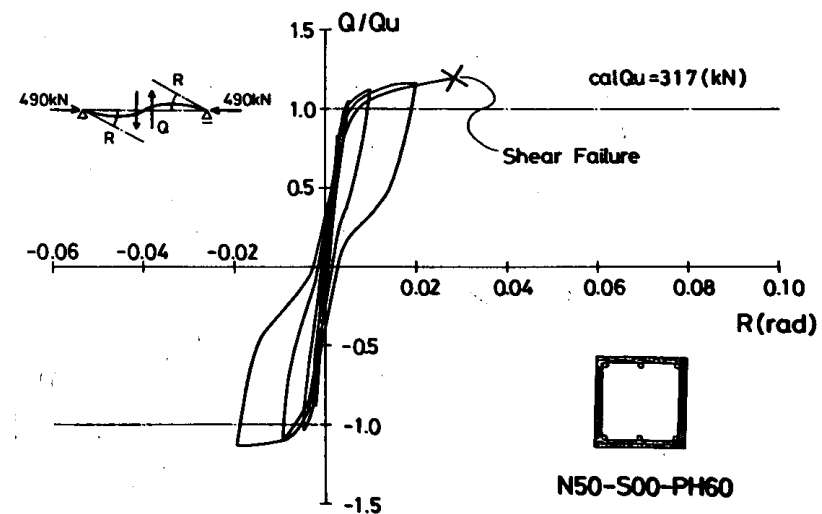

(b ) N50-S00-PH60
係である。目標最大部材角である1/12.5 $\mathrm{rad}$ 到るまで ほとんど耐力低下が見られず、安定した復元力特性を示 している。

図ー4（a）は、通常形式で横補強筋が $60 \mathrm{~mm}$ 間隔で入っ ているN46-S00-A60の荷重一変形関係である。第 2 サイ クル $(1 / 200 \mathrm{rad})$ の負方向ピーク時にせん断破壊し、軸 カを保持できなくなった。

一方、図-4(b) は、N46-S00-A60と同一条件で、鋼 板が60mm間隔で挿入されているN46-S60-A60の荷重一変 形関係である。第 4 サイクル (i/50 rad) の正方向で耐 力が増大しなくなり、第 5 サイクル $(1 / 25 \mathrm{rad})$ の負方 向ピーク時にせん断破壊し、軸力を保持できなくなっ た。

鋼板を挿入した試験体においては、曲げひび割れの早 期発生が認められ、その後もせん断破壊に進展すること なく安定した復元力特性を示している。最大耐力は、通 常形式のものに比べやや大きくなっており、横補強管 $30 \mathrm{~mm}$ 間隔の試験体で 1.07 倍、60mm間隔の試験体で 1.04 倍 となっている。鋼板を入れて水平ひび割れを誘導するこ とが、曲げ耐力の劣化にはつながらないことが判明し た。

図ー5（a）は、鋼板フープを $30 \mathrm{~mm}$ 間隔で入れ、かぶり 部分のみを分断したN50-S00-PH30に関する実験結果であ る。第 5 サイクル $(1 / 25 \mathrm{rad})$.載荷中に急激なせん断破
壊を起こし、軸力保持ができなくなった。

図ー5（b）は、鋼板フープを $60 \mathrm{~mm}$ 間隔で入れたN50S00-PH60に関する実験結果である。N50-S00-PH30同様、

第 5 サイクル（1/25rad）載荷中に急激なせん断破壊を 起こし、軸力保持ができなくなった。”

鋼板フープを用いた試験体は、ひび割れの発生とその 進展状況および勒性の改善ともに鋼板を挿入した試験体 ほど顕著ではないものの同様の性状を示している。

写真－1（a）に通常形式の試験体N40-S00-A30の最終破 壊状況を示す。斜めひび割れは試験体の圧縮縁を結ぶ線 上に生じており、ひび割れ上下端でコンクリートの圧壊 が起こっていた。ひび割れを横切る横補強筋の大半は切 断していた。

写真ー 1（b）は、鋼板によりコンクリートを分断した 試験体N40-S30-A30の最終破壊状況である。第 1 サイク ル時に生じる水平ひび割れは挿入した鋼板に沿って起 こっていることが確認された。その後、鋼板間での斜め ひび割れは発生しているが、大変形時に到るまで部材全 長にわたりつながることはなく、部材端部での鋼板に 沿ったひび割れが拡大するだけであった。

写真－2（a）に通常形式の試験体N46-S00-A60の最終 破壊状況を示す。N40-S00-A30 と同様に、斜めひび割れ は試験体の圧縮縁を結ぶ線上に生じており、ひび割れ上 下端でコンクリートの圧壊および剥離が起こっていた。 


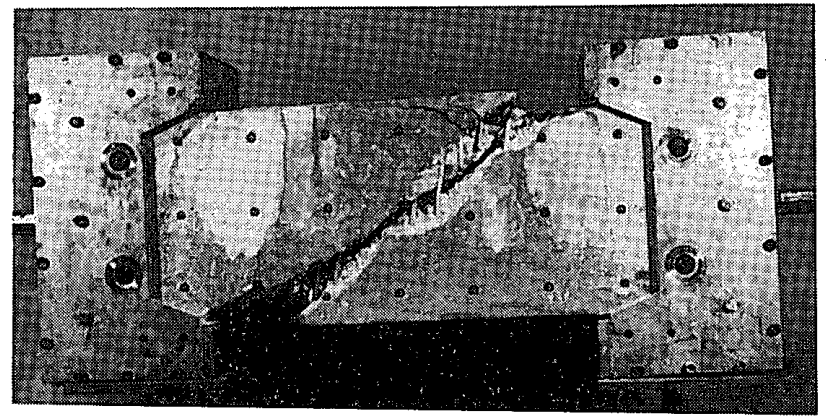

(a ) $\mathrm{N} 40-\mathrm{S} 00-\mathrm{A} 30$

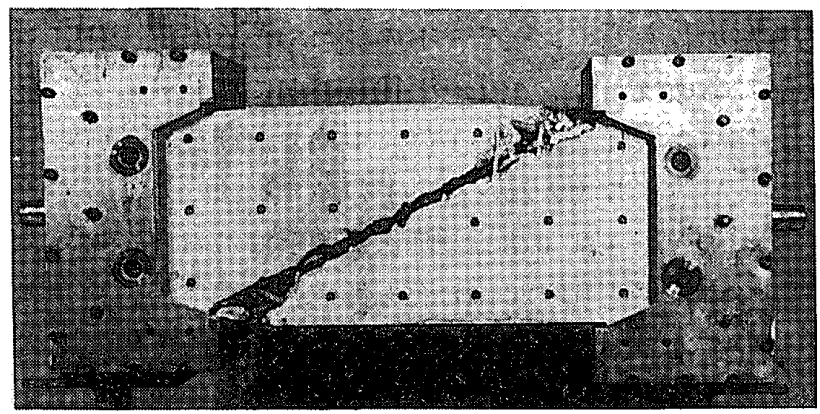

(a ) $\mathrm{N} 46-\mathrm{S} 00-\mathrm{A} 60$

写真 -2

ひび割れを横切る横補強筋の大半は切断していた。

写真－2（b）は、N46-S60-A60の最終破壊状況であ る。N40-S30-A30と同様に、第 1 サイクル時に生じる水 平ひび割れは挿入した鋼板に沿って起こっていることが 確認された。その後、第 2 サイクル時に鋼板間での斜め ひび割れが発生し、第 4 サイクルの正方向で鋼板間のひ び割れがつながり、引張側のコンクリートが剥離してい る。第 5 サイクル負方向ピーク時にせん断破壊を起こし 軸力を保持できなくなった。

\section{3 実験結果の考察}

図一 6 は、 6 体の試験体の限界変形角と横補強筋比の 関係を示したものである。限界変形角は、試験体ごとに 以下に示す方法で求めた。耐力が急激に低下した試験体 のうちN40-S00-A30およびN46-S00-A60は、経験した最大 変形角を、同じく耐力が急激に低下したN50-S00-PH30お よびN50-S00-PH60は、破壊した時の変形角を、耐力低下 を起こさなかったN40-S30-A30は、実験で与えた最大変 形を、ならびに正方向第 5 サイクルにおいて耐力低下し たN46-S60-A60は、最大耐力の $80 \%$ 低下時の変形角を、 それぞれ限界変形角とした。

曲げ降伏が先行する鉄筋コンクリート柱に対して、コ ンクリートの最大応力以降の負担応力の低下が断面の性 能劣化につながるとして、その限界変形角の計算式が提 案されている2), 3)。この計算式は、コアコンクリートの 応力ーひずみ関係を簡略化した 2 折線にモデル化するこ とにより限界変形角を求めようとするものである。せん 断破壊が先行する部材には、曲げ降伏後の勒性を評価し

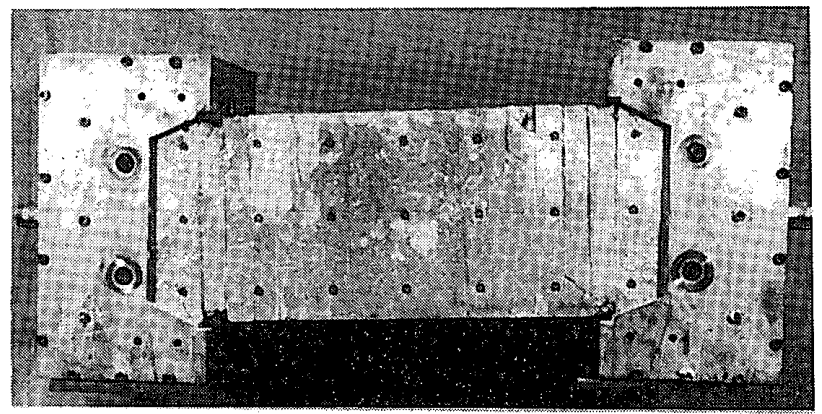

(b ) $\mathrm{N} 40-\mathrm{S} 30-\mathrm{A} 30$

最終破壊状況

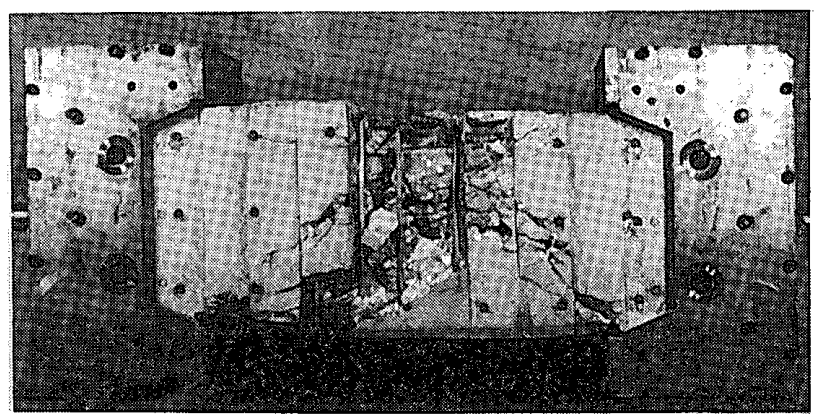

(b ) N46-S60-A60

最終破壊状況

ようとしたこの計算式は適用できない。6 6 体の試験体の うちN46-S00-A60を除く5体の試験体は、曲げ降伏が先 行しており、N46-S00-A60も最大耐力は曲げ耐力に達し ていることから、ここでは、横補強筋量と急激に耐力が 低下するときの変形角との関係を規定したこの計算式を 一つの評価尺度として用いている。

また、横補強笳を配した鉄筋コンクリート柱の応カー ひずみ関係は古くから提案されており、ここではそれら の研究のうち 2 つ提案式 5$), 6$, (7) を用いて上述の限界変 形角を算出する（具体的な算出方法については、付録に 示す）。これらの提案式は、いずれもプレーンコンク リートの応カーひずみ関係を基準に、横補強筋量の増加 に伴いコンクリートの強度が上昇し、最大耐力以降の劣 化勾配が緩やかになるとしたものである。これらの提案 式により求めた応力ーひずみ関係を 2 折線にモデル化し て算出した限界変形角を図中実線および点線で示す。

通常形式の試験体の限界変形角は、曲げ降伏の直後に せん断破壊したN46-S00-A60を除き、この計算式により ほぼ評価できる。また、鋼板フープによる試験体の限界 変形角は、計算值をやや上回っており、鋼板フープの分 断効果が認められる。鋼板によりコンクリートを分断 し、水平ひび割れをあらかじめ入れておくことを意図し た 2 体の限界変形角は、計算值を大幅に上回っており、 鋼板挿入効果が顕著に現れている。

仮に、鋼板を同一断面積の横補強筋に換算することに より、鋼板挿入効果のうち補強効果が評価できるものと して、N40-S30-A30とN46-S60-A60の等価横補強笳比を算 


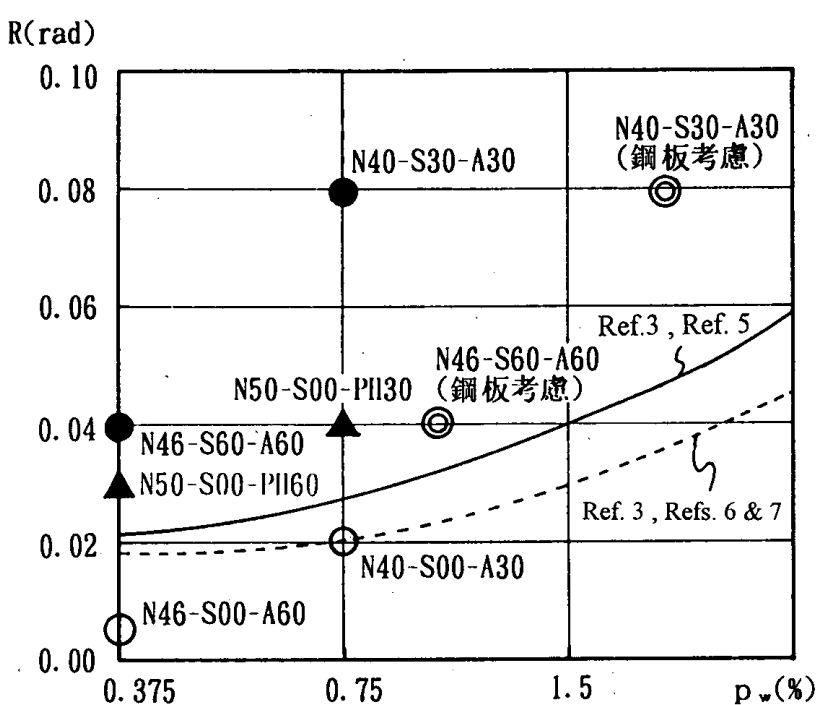

図－6 横補強筋比一限界变形角関係

出して示したのが、図中@印である。等価横補強筋比と いう尺度でみても実験值は計算值を上回っており、本仮 定条件のもとでは、その增大分がもう一つの鋼板挿入効 果である分断効果と考えられる。鋼板と横補強等の降伏 点は表ー 2 に示すように異なっているが、鋼板の降伏強 度の方が小さいこともあり、補強効果を最大に見積もる ものとして降伏強度の違いを無視している。

しかしながら、コンクリートと鎆板の間に十分な摩擦 力があれば、鋼板は試験体断面最外縁までコンクリート を拘束することになり、かぶりコンクリート部分が拘束 されていない通常の横補強筋による補強とは異なるた め、鋼板を同一断面積の横補強筋に換算した場合には、 この点を無視したことになる。このコンクリートと鋼板 との摩擦による力の伝達は、圧縮側断面では考えられる が、引張側では考えにくい。

このように、鋼板の補強効果として、鋼板を同一断面 積の横補強筋に換算して想定することは困難であり、鋼 板を挿入することによる勒性改善効果、鋼板フープによ る勒性改善効果ともにその効果のうちどの部分が分断効 果であり、どの部分が補強効果であるというように明快 な分離はできなかった。

ここで強調したいのは、鉄筋コンクリート部材の勒性 を向上させるための方法の多梯性であり、従前の考え方 にはなかったコンクリートを水平に分断するように鋼板 を挿入するという方法が、勒性を向上させる上で極めて 有効であることを明らかにしたことである。

このような方式が勒性向上のために有効であるのであ れば、コンクリートの単純な圧縮に対しても有効である と考えられる。なぜならば、単純圧縮を受ける場合も、 曲げせん断を受ける場合と同様に斜めひび割れが破填あ るいは強度低下に大きな影響を与えていると考えている
からである。次章に示す一軸圧縮実験は、そのことを確 認するために行ったものである。

\section{4.一軸圧縮実験}

\section{1 実験概要}

本実験は、圧縮方向と垂直に鋼板を入れ、コンクリー 卜を分断した場合の一軸圧縮特性を確認するために行っ ている。横補強筋は、用いていない。

\section{（1）試験体}

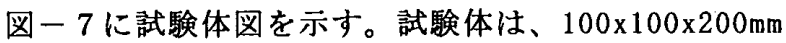
の直方体である。実験のパラメータは、試験体を分断す る鋼板の枚数とコンクリートの種類である。

試験体数は、コンクリート種類ごとに、試験体を分断 する鋼板を入れないもの 1 体、1 枚および 3 枚入れたも の各々 2 体、 5 枚入れたもの 1 体の 4 種類 6 体としてい る。鋼板の厚さは $0.8 \mathrm{~mm}$ 、降伏点強度は277MPaである。 鋼板には中央に直径 $20 \mathrm{~mm}$ の孔を開け、試験体の連続性を 確保している。連続している部分は、全断面に対して約 $3 \%$ あでり、その影響は小さいものと考えている。コン クリートの種類は、水セメント比 $55 \% ， 40 \%$ の 2 種類で、 その粗骨材の最大粒径は $10 \mathrm{~mm}$ である。試験体は、コンク リート打設後 24 時間で脱型し、その後標準養生した。

（2）加力および測定方法

圧縮実験は、コンクリート打設後材令 14 日に、アム スラー型万能試験機で行った。

測定は、加力時の荷重と試験体の鉛直変位である。鉛 直変位は試験機の球座と台座の間に取り付けた左右 2 個 のダイヤルグージにより測定し、その平均值を測定值と している。

\section{2 実験結果}

図ー8（a）は、水セメント比55\%の場合の忘カーひず み関係である。鋼板を配置したことによる影響が顕著に 現れていることがわかる。鋼板を配㯰することにより最 大耐力が増加し、最大耐力時のひずみはそれに伴い大き くなった。また、最大耐力後の剛性低下も緩やかになっ

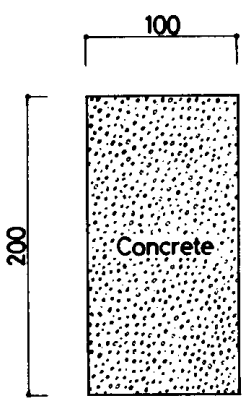

No plate

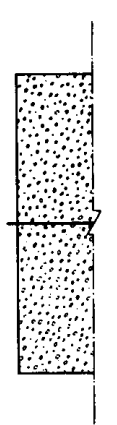

1 plate

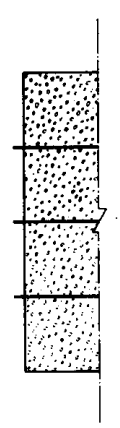

3 plates

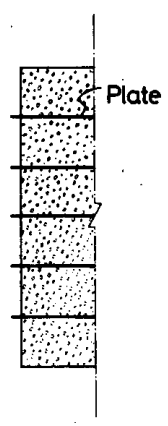

5 plates
Prism : $100 \times 100 \times 200(\mathrm{~mm})$

図 -7 試験体図 


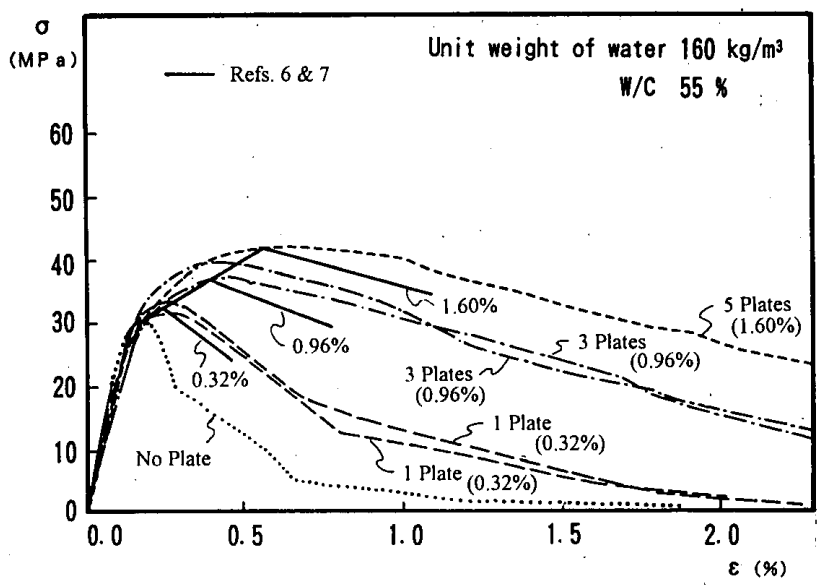

(a) $\mathrm{W} / \mathrm{C}=55 \%$

図 -8 応力ーひずみ関係

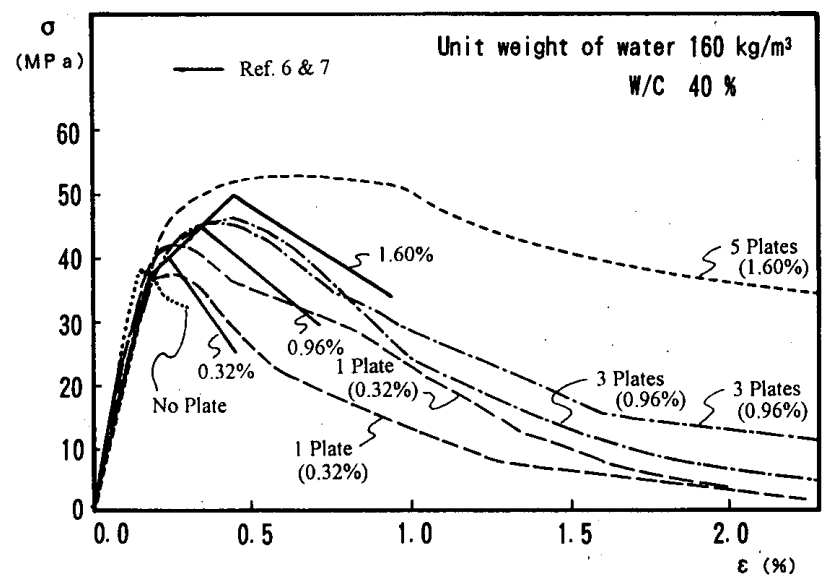

(b) $\mathrm{W} / \mathrm{C}=40 \%$
ており、その傾向は鋼板の枚数が増すにつれ顕著になっ ている。コンクリートを分断するように入れた鋼板が斜 めひび割れの発生を防止あるいは遅延させているため に、コンクリートの一軸圧縮時の特性が改善しているも のと考えられる。

図－8（b）は水セメント比40\%の場合の応力ーひず 関係である。全体の傾向は水セメント比 $55 \%$ の場合と同 様であるが、鋼板を入れていない試験体は高強度のもの ほど最大耐力以降の剛性低下がより脆性的である。ま た、鋼板を入れている試験体では、その圧縮勒性の改善 効果は高強度のものほど顕著になっている。

\section{3 実験結果の考察}

3 章で示した曲げせん断実験では、鋼板の間隔は横補 強笳の間隔と同一であり、コアコンクリートの幅に対し て3/20ないしは6/20となっている。一軸圧縮実験の結果 からは、断面幅の 3 分の 1 程度の間隔（鋼板枚数 5 枚に 相当）でコンクリートを分断すれば圧縮勒性が十分改善 できると言える。

鋼板を同一断面積の横補強笳に換算するとその横補強 筋比は、鋼板 1 枚のものが $0.32 \% 、 3$ 枚が $0.96 \% 、 5$ 枚が $1.6 \%$ となるこの補強筋筋比に対する応力ーひずみ関係 を、図一8(a) および(b) にあわせて示している。応力 一ひずみ関係は、コンファインドコンクリートの提案式 のうち、本実験に用いたコンクリート強度の範囲では、 横補強筋の効果を大きめに評価している式6), 7)か求め ている。実験結果は、この提案式により求めた結果より も安定したものとなっており、コンクリート強度の大き いものほど、鋼板を挿入する効果がより顕著に現れてい る。

この応力ーひずみ関係の提案式は、横拘束筋で囲まれ たコアコンクリート部分を対象としたもので、圧縮曲げ せん断実験の場合に論じたかぶりコンクリート部分の拘 束の影響を無視できるため、鋼板の補強効果の評価は、 より単純である。ただし、コンクリートを横補強筋で拘 束することと鋼板で面的に補強材を分散させて拘束する
ことの相異はあり、ここでも、摩擦その他、その評価が 困難な面を何点か含んでいるので、鋼板挿入効果を分断 効果と補強効果とに分離する議論は行わず、鋼板挿入効 果として論ずる。

図ー8によれば、鋼板を挿入した試験体10体のうち、 鋼板を同一断面積の横補強筋に換算し、既往の研究成果 6),7)によって想定したみかけ上の応力ーひずみ関係の最 大耐力より下回っているものが 2 体（鋼板 1 枚のもの） であり、耐力低下も想定されたものと同等か、より小さ いものとなっている。試験体によるバラツキを考虑して も、鋼板挿入効果は、同一断面積の横補強筋による補強 効果を上回っていると言える。

\section{5. 結論}

1 ）圧縮曲げせん断を受ける鉄筋コンクリート部材の 材軸と直角に鋼板を挿入することにより、曲げひび割れ の早期発生およびその部分への変形集中が生じる。ま た、部材全長にわたる幅の大きな斜めひび割れの発生を 防止あるいは遅延させることができ、勒性を大きく改善 することができる。

2）鋼板による靬性改善効果は、鋼板を同一断面積の 横補強筋に換算して想定した靬性改善効果より大きい。

3）鋼板フープで補強した柱においても、鋼板を挿入 した柱ほど顕著ではないが同様な効果が認められ、鋼板 フープ柱は、鋼板フープと同一断面積の通常の横補强筋 で補強した柱より鞄性が高い。

4) 鋼板を挿入する効果は、純圧縮においても認めら れ、鋼板を挿入した試験体のみかけ上の応力ーひずみ関 係は、鋼板を同一断面積の横補強筋に換算して既往の提 案式を用いて求めたコンファインドコンクリートの応力 ーひずみ関係より安定している。

実験結果に基づく具体的な知見は以上の通りである が、最も重要なことは、鉄筋コンクリートの勒性を向上 させる手法の幅広さを示したことである。本実験では、 勒性改善効果の影響因子ごとの明快な分離はできなかっ 
たが、十分に定着が確保されているとは言い難い鋼板が

極めて効果的であった。

\section{考文献}

1 ）日本建築学会：鉄筋コンクリート造建物の終局強度型耐震 設計指針・同解説，昭和 63 年

2 ）平石久廣，稲井栄一：鉄筋コンクリート造柱の曲げ降伏後 の鞄性に関する解析的研究;, 日本建築学会構造系論文報告 集, 第 408 号, pp. $21-30$, 平成 2 年 2 月

3) 日本建築学会鉄筋コンクリート構造運営委員会：勒性設計 小委員会報告書（終局强度型耐覀設計法に関連する最新の 研究成果)，pp. 95-102, 平成 4 年 8 月

4) -鈴木敏郎，滝口克己，垭田久人：鉄筋コンクリート柱の変 形機樓の制御，コンクリート構造物の勒性と配㳙方法に関 するシンポジウム論文集，pp. 205-210，平成 2 年 5 月

5.) 西山峰広, 六車熙, 井上弘行：横拘束によるコンクリート 系部材の曲げ勒性改善, コンクリート構造物の勒性とその 評価法に関するコロキウム論文集，II，pp. 33-44，昭和 53 年 3 月

6) 鈴木計夫, 中塚佶, 吉田晴彦: 円形横補强管を用いたコン ファインドコンクリートの強度および変形特性，材料，第 34巻，第376号, pp. 33-394, 昭和60年 1 月

7) 鈴木計夫, 中塚佶，菅田昌宏：角形横補强筋によるコン ファインドコンクリートの拘束機構と蚛度・変形特性, コ ンクリート工学年次論文報告集，11-2，pp. 449-460，平成 元年

付 録 図 6 および図 8 に示す計算值の算出方法について

図 6 および図 8 に示す計算値の算出方法は、文献 5 および文 献 6，7で提案されている応カーひずみ関係を付図-1のよう にモデル化し、文献 3 に示されている限界変形角算出式にあて はめることにより導いている。文献 3 に示されている限界変形 角算出式は、以下のようである。

$$
\begin{aligned}
& \mathrm{R}=\frac{\mathrm{d}_{1}}{2_{i} \alpha \eta_{\mathrm{c}}}\left\{1+\alpha-\left(\frac{\eta_{\mathrm{c}}}{\mathrm{d}_{1}}\right)^{2}\right\} \frac{\varepsilon_{\mathrm{B}} \mathrm{D}}{\mathrm{d}_{1} \mathrm{D}^{\prime}} \\
& \mathrm{R} \text { ：限界変形角 (rad) } \\
& \mathrm{D} \quad \text { ：柱せい }(\mathrm{cm}) \\
& \mathrm{D}^{\prime} \text { : こア柱せい }(\mathrm{cm}) \\
& \mathrm{B}^{\prime}: \text { : コア柱幅 }(\mathrm{cm}) \\
& \text { d，：圧縮縁から引㖘主筋までの距離の柱せいに対す } \\
& \text { る比 } \\
& \mathrm{f}_{c}^{\prime} \text { : : コアコンクートの圧縮强度 }\left(\mathrm{kg} / \mathrm{cm}^{2}\right) \\
& \varepsilon_{\mathrm{B}} \text { ：コアコンクリートの圧樎強度時のひずみ } \\
& \alpha \text { : 耐力少化勾配の初期勾配に対する比 } \\
& \eta_{\mathrm{c}}: \text { : アコンクリートの負担軸力比 }
\end{aligned}
$$

\begin{tabular}{|c|c|}
\hline & 表 示 式 \\
\hline $\begin{array}{c}\text { [著者] } \\
\text { 西山 }\end{array}$ & 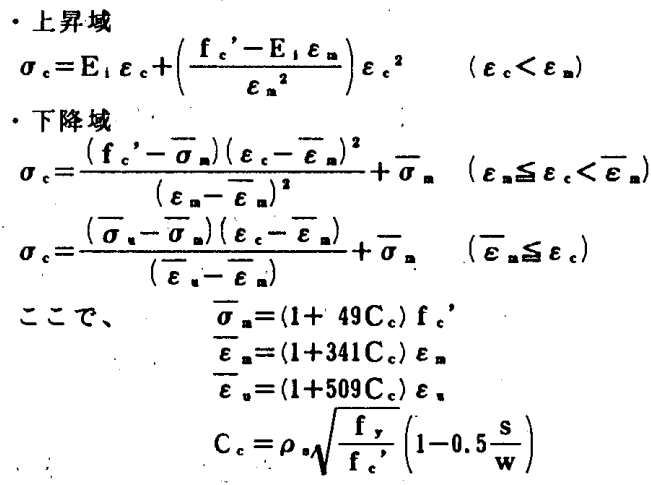 \\
\hline $\begin{array}{c}\text { [著者] } \\
\text { 鈴木 } \\
\text { 中塚 } \\
\text { 营田 }\end{array}$ & 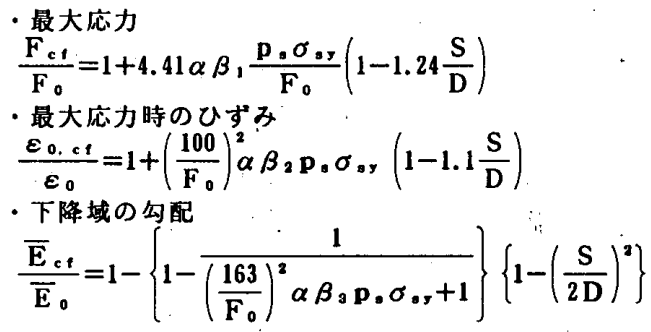 \\
\hline
\end{tabular}

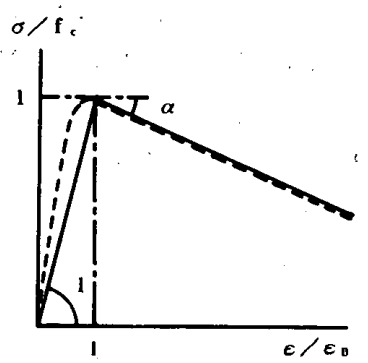

付図ー1 応カーひずみ関係のモデル化
また、文献 5 および文献 $6 ， 7$ で提案されている角形横補強 笳により拘束されたコアコンクリートの圧樎応カーひずみ関俰 は付表一1のように表されている。これらの関保式を図示する とそれぞれ付図ー2，3のようになる。（付 1 ）式を用いて限 界変形角を算出するには、これらの応力ーひずみ関係のうち最 大応力 $\mathrm{f}$ 、最大応力時のひずみ $\varepsilon_{\mathrm{B}}$ および応力劣化勾配 $\alpha$ がわ かればよいので、2つの関保式による応カーひずみ関係を付図 -1 に示す 2 折線にモデル化して $\mathrm{f}_{c}, \varepsilon_{\mathrm{B}}, \alpha$ を求めている。

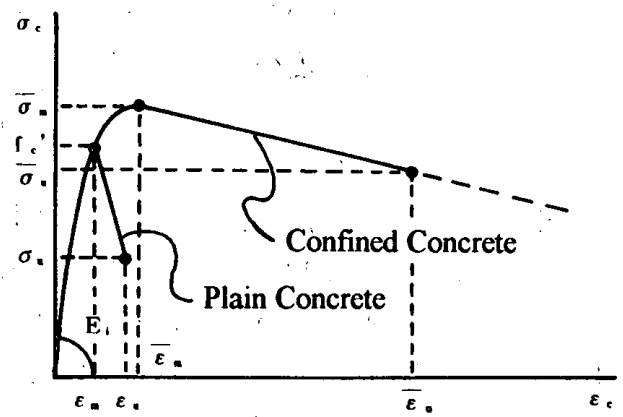

付図ー2：応力ーひずみ関倸（文献 5 ）

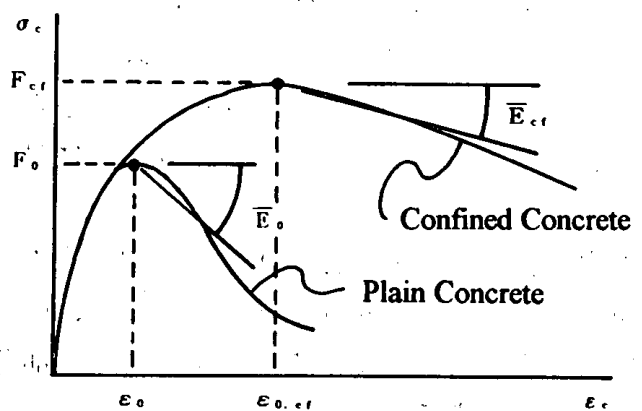

付図-3 応力ーひずみ関係（文献 6 ）

(1993 年 7 月 9 日原稿受理, 1993 年 12 月 27 日採用決定) 